\title{
Ticks infesting birds in Atlantic Forest fragments in Rio Claro, State of Sao Paulo, Brazil
}

\author{
Carrapatos infestando aves em fragmentos de Mata Atlântica em Rio Claro, São Paulo, Brasil \\ Gustavo Seron Sanches ${ }^{1 *}$; Thiago Fernandes Martins²; Ileyne Tenório Lopes ${ }^{1}$; Luís Flávio da Silva Costa ${ }^{1}$; \\ Pablo Henrique Nunes ${ }^{1}$; Maria Izabel Camargo-Mathias ${ }^{1}$; Marcelo Bahia Labruna ${ }^{2}$
}

\begin{abstract}
${ }^{1}$ Departamento de Biologia, Instituto de Biociências, Universidade Estadual Paulista - UNESP, Rio Claro, SP, Brasil
${ }^{2}$ Faculdade de Medicina Veterinária Preventiva e Saúde Animal, Universidade de São Paulo - USP,

Sáo Paulo, SP, Brasil
\end{abstract}

Received January 27, 2012

Accepted March 19, 2012

\begin{abstract}
In the present study, we report tick infestations on wild birds in plots of the Atlantic Forest reforested fragments with native species and plots reforested with Eucalyptus tereticornis in the municipality of Rio Claro, State of Sao Paulo, Brazil. A total of 256 birds were captured: 137 individuals of 33 species, in planted native forest; and 128 individuals of 37 species, in planted Eucalyptus tereticornis forest. Nymphs of two tick species were found on the birds: Amblyomma calcaratum and Amblyomma longirostre, the former was more abundant in the fragments reforested with Atlantic forest native species, and the latter in the fragment reforested with E. tereticornis. New host records were presented for $A$. calcaratum.
\end{abstract}

Keywords: Wild birds, Amblyomma, reforested fragments.

\section{Resumo}

O presente estudo apresenta infestaçóes de carrapatos em aves silvestres em fragmentos de reflorestamento com espécies nativas e fragmentos de reflorestamento com Eucalyptus tereticornis no município de Rio Claro, São Paulo. No total foram capturadas 265 aves, sendo 137 indivíduos de 33 espécies nas áreas de reflorestamento com espécies nativas e 128 indivíduos de 37 espécies nas áreas reflorestadas com Eucalyptus tereticornis. Ninfas de duas espécies de carrapatos foram registradas: Amblyomma calcaratum e Amblyomma longirostre, sendo a primeira mais abundante na área nativa e a segunda na área de Eucalyptus tereticornis. Novos registros de hospedeiros para A. calcaratum são apresentados.

Palavras-chave: Aves silvestres, Amblyomma, fragmentos reflorestados.

\section{Introduction}

Ticks are obligate hematophagous ectoparasites commonly found all around the world parasitizing an enormous variety of hosts, from amphibians and reptiles to birds and mammals (ONOFRIO et al., 2006). They can transmit many pathogens to animals and humans during blood feeding (JONGEJAN; UILENBERG, 2004).

Wild birds can act as long-distance vectors for several microbial agents of human disease, including viruses, chlamydiae, enterobacteria, and spirochetes (BJÖERSDORFF et al., 2001; GEORGOPOULOU; TSIOURIS, 2008). They are also incidentally

\footnotetext{
${ }^{*}$ Corresponding author: Gustavo Seron Sanches

Departamento de Biologia, Instituto de Biociências, Universidade Estadual Paulista - UNESP, Av. 24 A, 1515, CP 199, CEP 13506-900,

Rio Claro, SP, Brasil

e-mail: gustavoseron@hotmail.com
}

found infected by rickettsiae (SANTOS-SILVA et al., 2006; ELFVING et al. 2010; HILDEBRANDT et al., 2010), Babesia spp. and Anaplasma spp. (HILDEBRANDT et al., 2010).

The Brazilian bird fauna is one of the largest in the world, comprising around 1,832 species (CBRO, 2011). Recently, some studies have contributed to improve the data concerning ticks infesting Brazilian birds in the Amazon region (OGRZEWALSKA et al., 2010), and Atlantic Forest (OGRZEWALSKA et al., 2008, 2011; LABRUNA et al., 2007) and Cerrado (TOLESANO-PASCOLI et al., 2010).

In the present study, we reported tick infestations on wild birds in reforestation fragments with native Atlantic forest species and reforestation fragments with Eucalyptus tereticornis in the centraleastern region of the State of Sao Paulo, Brazil. 


\section{Materials and Methods}

\section{Study area}

This study was conducted in "Edmundo Navarro de Andrade" forest, located in the municipality of Rio Claro, State of Sao Paulo, Brazil $\left(22^{\circ} 25^{\prime} \mathrm{S}\right.$ and $47^{\circ} 33^{\prime} \mathrm{W}$ ) (Figure 1). It is a protected area of stational semidecidual forest (Atlantic Forest) with fragmented regions of Cerrado and regions of reforestation. The study area was composed of four plots of Atlantic forest reforested with native species over 70 years ago (each plot represents a large planting field): N1 (7.6 ha), N2 (2.7 ha), N3 (1.6 ha) and N4 (1.0 ha), and four plots of Eucalyptus tereticornis over 80 years old: E1 (9.0 ha), E2 (11.0 ha), E3 (8.2 ha) and E4 (5.5 ha) (Figure 2). The Eucalyptus plots suffered selective logging over the years, reducing density and allowing for regeneration of native vegetation.

\section{Bird capture}

Between April 2009 and March 2010, wild birds were caught inside the reforestation plots using ten mist nets $(12 \mathrm{~m}$ long $\times 2.5 \mathrm{~m}$ wide, $35 \mathrm{~mm}$ mesh). In each area, mist nets were left open from 6 AM. to 12 PM., totalizing 1,890 net-hours (56,700 h.m²). Bird species were identified according to Sick (1997), Souza (2002) and Sigrist (2009). Captured birds were carefully examined for the presence of ticks by checking their whole body. All ticks found attached to birds were removed with forceps. Before being released, the captured birds were marked with leg bands supplied by the 'Centro Nacional de Pesquisa para Conservação de Aves Silvestres', 'Instituto Chico Mendes de Conservação da Biodiversidade' (CEMAVE/ICMBIO) to verify any recapture, which were not considered in the counting. Thereafter, birds were released at the same site. Ticks removed from birds were placed in 70\% alcohol and identified in laboratory for Amblyomma nymphs following Martins et al. (2010). Larval ticks were morphologically identified to the genus level. Tick specimens collected during this study were deposited in the tick collection "Coleção Nacional de Carrapatos" (CNC) of the Faculdade de Medicina Veterinária Preventiva e Saúde Animal, Universidade de São Paulo - USP, São Paulo, Brazil.

Field data of ticks on birds were used to calculate the prevalence and mean intensity of tick infestations on each bird species. These calculations were performed according to the concepts reported by Bush et al. (1997), where prevalence is the number of infested birds divided by the number of examined birds multiplied by 100 for each bird species, and mean intensity is the total number of ticks divided by the number of infested birds for each bird species. The overall prevalence of infested birds from native and eucalyptus plots was compared by the chi-square distribution using Minitab ${ }^{\circledast}$ release 15 .

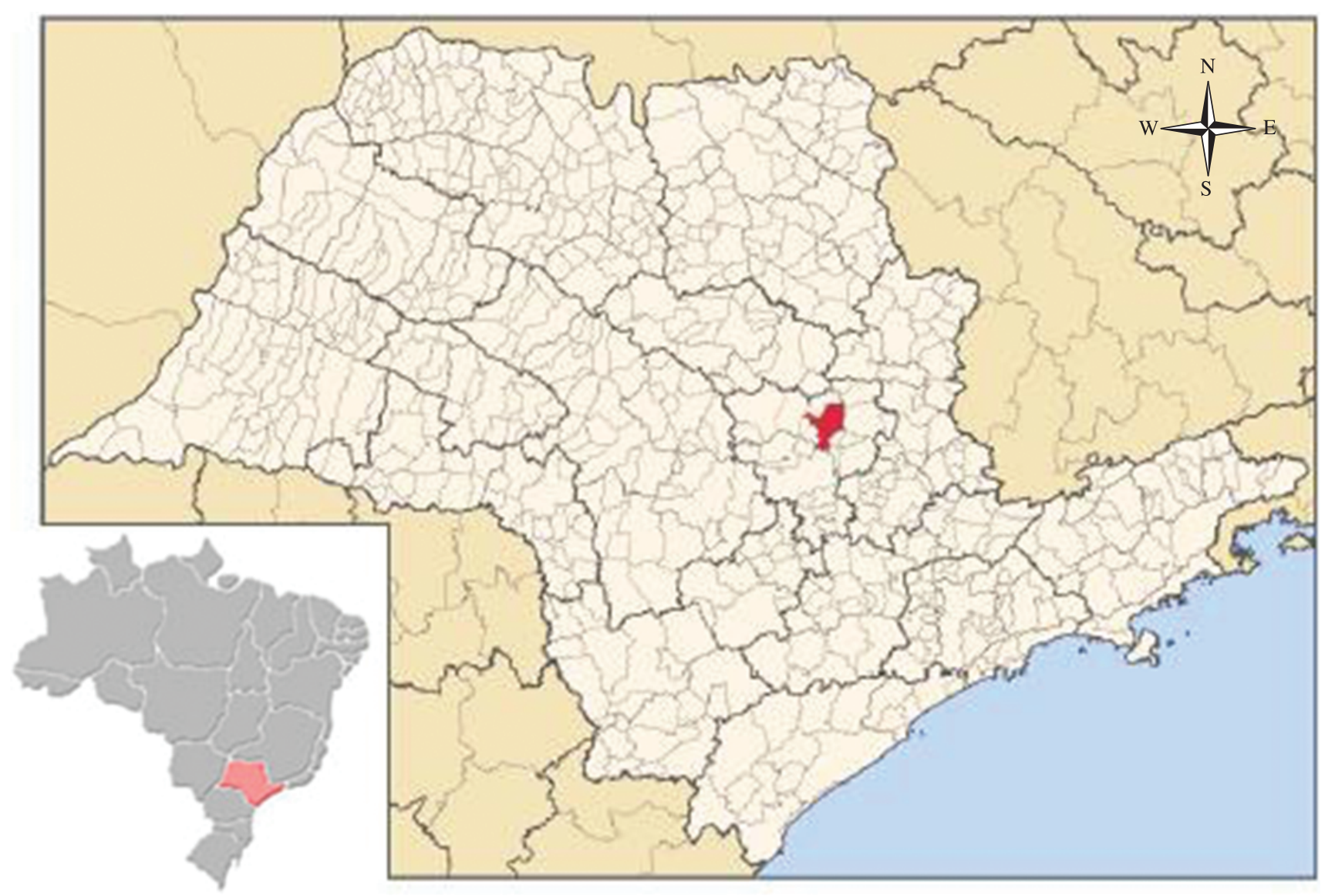

Figure 1. Location map - municipality of Rio Claro, State Sao Paulo, Brazil. 


\section{Results}

A total of 265 birds from 45 different species were captured: 137 birds of 33 species belonging to 18 families captured in planted native forest, and 128 birds of 37 species belonging to 19 families captured in planted Eucalyptus tereticornis forest. Two species of ticks were recovered from birds during this study:
Amblyomma longirostre (Koch, 1844) and Amblyomma calcaratum (Neumann, 1899). Out of the 137 birds captured in native forest, $10(7.3 \%)$ were parasitized by ticks: 19 Amblyomma sp. larvae, three A. longirostre nymphs, and $10 \mathrm{~A}$. calcaratum nymphs. The species with the highest mean intensity of ticks were Turdus leucomelas and Antilophia galeata, with 2.6 and 3 ticks/bird, respectively (Table 1). Of the 128 species of birds captured in Eucalyptus

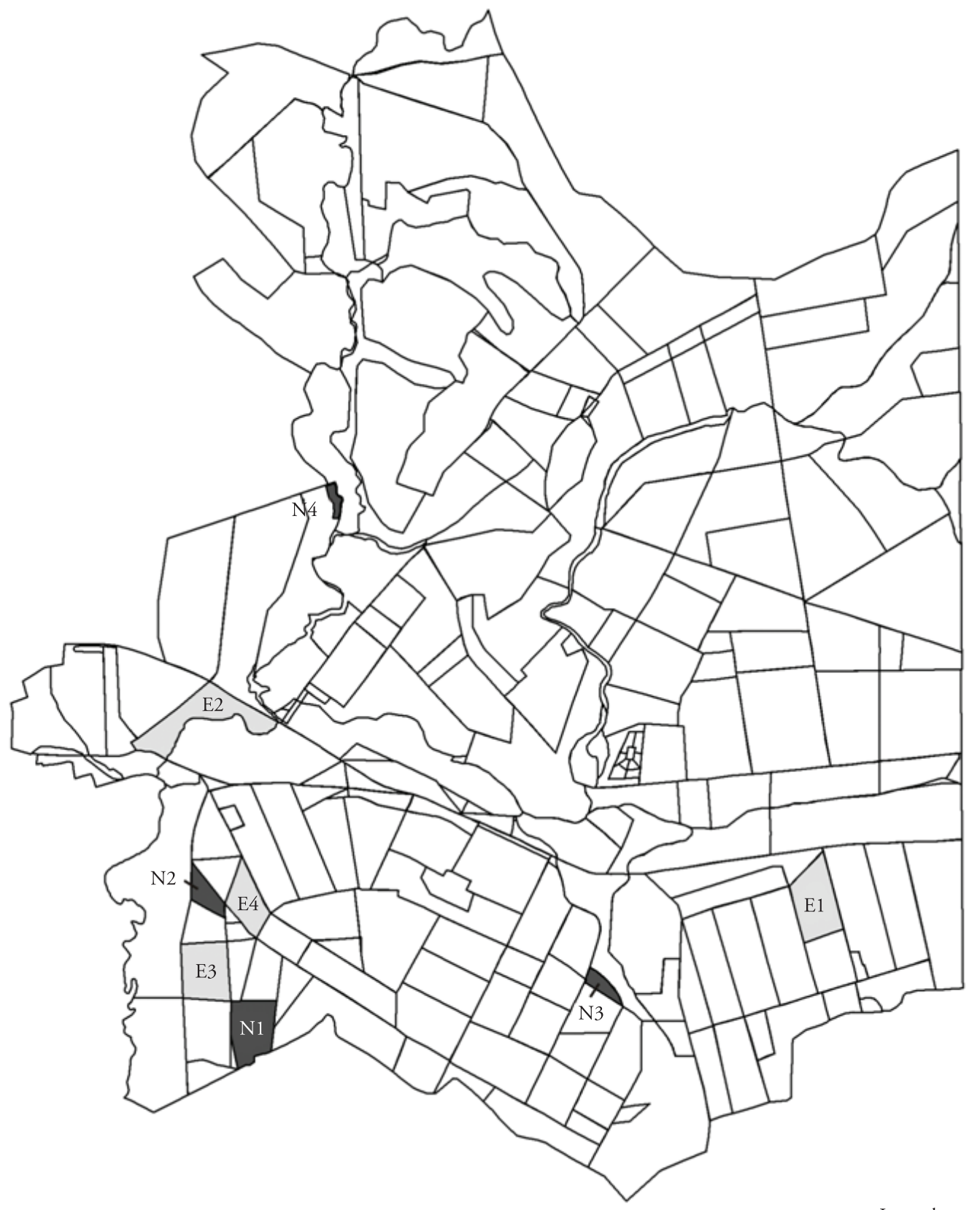

Legend:

Figure 2. Location map of the study area. 
Table 1. Ticks collected on birds in fragments of reforestation with native Atlantic forest species in the municipality of Rio Claro, State of Sao Paulo, Brazil.

\begin{tabular}{|c|c|c|c|c|c|c|c|}
\hline Birds & & & & & & Ticks & \\
\hline Family & Species (No. Captured) & No. Infested & Prevalence & $\begin{array}{c}\text { Mean } \\
\text { instensity }\end{array}$ & Area & $\begin{array}{c}\mathrm{No}^{\circ} \\
\text { Larvae - Genus }\end{array}$ & $\begin{array}{c}\text { No. } \\
\text { Nymphs - Species }\end{array}$ \\
\hline Falconidae & Micrastur semitorquatus (1) & 0 & 0 & 0 & N1 & & \\
\hline \multirow[t]{2}{*}{ Columbidae } & Leptotila verreauxi (4) & 0 & 0 & 0 & $\mathrm{~N} 1, \mathrm{~N} 2$ & & \\
\hline & Geotrygon violacea (1) & 0 & 0 & 0 & N3 & & \\
\hline Trochilidae & Amazilia versicolor $(1)$ & 0 & 0 & 0 & N3 & & \\
\hline \multirow[t]{2}{*}{ Picidae } & Picumnus albosquamatus (1) & 0 & 0 & 0 & N1 & & \\
\hline & Veniliornis passerinus (1) & 0 & 0 & 0 & N3 & & \\
\hline \multirow[t]{3}{*}{ Thamnophilidae } & Thamnophilus doliatus (1) & 0 & 0 & 0 & N1 & & \\
\hline & Thamnophilus caerulescens (2) & 0 & 0 & 0 & $\mathrm{~N} 2$ & & \\
\hline & Dysithamnus mentalis (1) & 1 & 100 & 2 & N3 & & 2A. calcaratum \\
\hline Conopophagidae & Conopophaga lineata (3) & 0 & 0 & 0 & $\mathrm{~N} 1, \mathrm{~N} 2$ & & \\
\hline \multirow[t]{2}{*}{ Dendrocolaptidae } & Sittasomus griseicapillus (G) & 0 & 0 & 0 & N1, N3 & & \\
\hline & Dendrocolaptes platyrostris ( 7 ) & 0 & 0 & 0 & $\begin{array}{l}\mathrm{N} 1, \mathrm{~N} 2, \\
\mathrm{~N} 3\end{array}$ & & \\
\hline \multirow[t]{2}{*}{ Furnariidae } & Synallaxis ruficapilla (3) & 0 & 0 & 0 & N2 & & \\
\hline & Automolus leucophthalmus (2) & 1 & 50 & 2 & N3, N4 & 2 Amblyomma sp. & \\
\hline \multirow[t]{4}{*}{ Tyrannidae } & Tolmomyias sulphurescens (5) & 0 & 0 & 0 & $\mathrm{~N} 1, \mathrm{~N} 2$ & & \\
\hline & Leptopogon amaurocephalus (2) & 0 & 0 & 0 & N3 & & \\
\hline & Platyrinchus mystaceus (G) & 1 & 16.6 & 2 & $\begin{array}{l}\mathrm{N} 1, \mathrm{~N} 2, \\
\mathrm{~N} 3\end{array}$ & 2 Amblyomma sp. & \\
\hline & Lathrotriccus euleri (7) & 0 & 0 & 0 & $\begin{array}{l}\text { N1, N2, } \\
\quad \text { N3 }\end{array}$ & & \\
\hline Pipridae & Antilophia galeata (3) & 1 & 33.3 & 3 & $\begin{array}{l}\text { N1, N2, } \\
\text { N4 }\end{array}$ & 3 Amblyomma sp. & \\
\hline \multirow[t]{4}{*}{ Thraupidae } & Lanio penicillatus (5) & 2 & 40 & 1 & N1, N3 & & 2 A. longirostre \\
\hline & Lanio melanops $(7)$ & 3 & 50 & 1 & $\begin{array}{l}\mathrm{N} 1, \mathrm{~N} 2 \\
\mathrm{~N} 3, \mathrm{~N} 4\end{array}$ & & $\begin{array}{l}2 \text { A. calcaratum; } \\
1 \text { A. longirostre }\end{array}$ \\
\hline & Tachyphonus coronatus (1) & 1 & 100 & 2 & N1, N4 & 2 Amblyomma sp. & \\
\hline & Tangara sayaca $(1)$ & 0 & 0 & 0 & $\mathrm{~N} 2$ & & \\
\hline Vireonidae & Cyclarhis gujanensis (1) & 0 & 0 & 0 & N1 & & \\
\hline \multirow[t]{2}{*}{ Turdidae } & Turdus rufiventris (3) & 1 & 33.3 & 2 & $\begin{array}{l}\text { N1, N2, } \\
\quad \text { N4 }\end{array}$ & 2 Amblyomma sp. & \\
\hline & Turdus leucomelas (28) & 5 & 17.8 & 2.6 & $\begin{array}{l}\mathrm{N} 1, \mathrm{~N} 2, \\
\mathrm{~N} 3\end{array}$ & 8 Amblyomma sp. & 5 A. calcaratum \\
\hline \multirow[t]{2}{*}{ Emberizidae } & Volatinia jacarina (1) & 0 & 0 & 0 & N1 & & \\
\hline & Arremon flavirostris (3) & 1 & 33.3 & 1 & $\mathrm{~N} 1, \mathrm{~N} 2$ & & 1 A. calcaratum \\
\hline Cardinalidae & Habia rubica (4) & 0 & 0 & 0 & N2, N3 & & \\
\hline \multirow[t]{3}{*}{ Parulidae } & Basileuterus hypoleucus (3) & 0 & 0 & 0 & $\mathrm{~N} 1, \mathrm{~N} 2$ & & \\
\hline & Basileuterus flaveolus (11) & 0 & 0 & 0 & $\begin{array}{l}\text { N1, N2, } \\
\text { N3 }\end{array}$ & & \\
\hline & Basileuterus leucoblepharus (1) & 0 & 0 & 0 & $\mathrm{~N} 2$ & & \\
\hline
\end{tabular}

No - number.

stands, 12 (9.3\%) were infested with ticks: 34 Amblyomma sp. larvae, two $A$. calcaratum nymphs, and nine $A$. longirostre nymphs. Individual infestations usually consisted of few ticks, with mean intensity lower than two ticks/bird (Table 2). The bird species Habia rubica and Platyrinchus mystaceus moved between the plots. H. rubica and Dendrocolaptes platyrostris also moved between the plots, but they were not found parasitized with ticks. Prevalence values of infested birds were statistically similar among native and eucalyptus plots $(\mathrm{Chi}-\mathrm{Sq}=0.375 ; \mathrm{DF}=1 ; P$-Value $=0.541)$.

\section{Discussion}

In this study, we report tick parasitism in wild birds captured in two distinct reforestation areas: plots planted with native species and plots with Eucalyptus tereticornis. The species richness of birds was similar in the two areas, since 33 and 37 bird species were captured in native and eucalyptus plots, respectively.

The tick $A$. calcaratum predominated among the nymphs collected on birds in fragments of native species, whereas 
A. longirostre predominated among the nymphs collected on birds in the E. tereticornis fragments; the latter fragments also presented higher abundance of Amblyomma sp. larvae.

The adult stage of $A$. calcaratum feeds almost exclusively on anteaters, while larvae and nymphs were found feeding on birds (GUGLIELMONE et al., 2003). Jones et al. (1972) cited immature stages of $A$. calcaratum on birds without species identification. Labruna et al. (2007) also recorded the occurrence of $A$. calcaratum nymphs parasitizing Saltator similis, Conopophaga lineata, Turdus albicollis, Chiroxiphia caudata and Pyriglena leucoptera captured in the interior of the State of Sao Paulo, Brazil, while birds captured on the coast of the same state were parasitized by $A$. nodosum. Labruna et al. (2007) speculated that larvae and nymphs of $A$. calcaratum host seek on the ground surface, since giant anteaters (Myrmecophaga tridactyla) are exclusively terrestrial (EMMONS; FEER, 1997).

Ogrzewalska et al. (2011) reported $A$. calcaratum nymphs parasitizing Conopophaga melanops, Dixiphia pipra and Manacus manacus in Atlantic forest. In the present study, we found additional species being parasitized for the first time by this tick: Dysithamnus mentalis, Lanio melanops, Turdus leucomelas, Arremon flavirostris and Lathrotriccus euleri. Indeed, these species have the habit to visit the ground to seek for food or collect material to build nests (SICK, 1997).

Table 2. Ticks collected on birds in fragments of reflorestation with Eucalyptus tereticornis in Rio Claro Municipality, State of São Paulo, Brazil.

\begin{tabular}{|c|c|c|c|c|c|c|c|}
\hline Birds & & & & & & Ticks & \\
\hline Family & Species (No. Captured) & $\begin{array}{c}\text { No. } \\
\text { Infested }\end{array}$ & Prevalence & $\begin{array}{c}\text { Mean } \\
\text { instensity }\end{array}$ & Area & $\begin{array}{c}\text { No. } \\
\text { Larvae - Genus }\end{array}$ & $\begin{array}{c}\text { No. } \\
\text { Nymphs - Species }\end{array}$ \\
\hline Columbidae & Leptotila verreauxi (2) & 0 & 0 & 0 & E1, E2 & & \\
\hline Trochilidae & Amazilia lactea (2) & 0 & 0 & 0 & E1, E3 & & \\
\hline Picidae & Picumnus albosquamatus (2) & 0 & 0 & 0 & E1, E2 & & \\
\hline \multirow[t]{5}{*}{ Thamnophilidae } & Taraba major (3) & 1 & 33.3 & 1 & $\mathrm{E} 2$ & & $1 \mathrm{~A}$. longirostre \\
\hline & Thamnophilus doliatus (1) & 0 & 0 & 0 & E2 & & \\
\hline & Thamnophilus caerulescens (4) & 0 & 0 & 0 & $\mathrm{E} 1, \mathrm{E} 2, \mathrm{E} 3$ & & \\
\hline & Dysithamnus mentalis (3) & 0 & 0 & 0 & E2, E3 & & \\
\hline & Pyriglena leucoptera (3) & 0 & 0 & 0 & E1, E3 & & \\
\hline Conopophagidae & Conopophaga lineata (11) & 1 & 9 & 1 & $\mathrm{E} 1, \mathrm{E} 2, \mathrm{E} 3$ & & 1 A. calcaratum \\
\hline \multirow[t]{2}{*}{ Dendrocolaptidae } & Sittasomus griseicapillus (5) & 1 & 20 & 2 & $\mathrm{E} 1, \mathrm{E} 2$ & & 2 A. longirostre \\
\hline & Dendrocolaptes platyrostris (1) & 0 & 0 & 0 & E1 & & \\
\hline Furnariidae & Synallaxis ruficapilla ( 7$)$ & 0 & 0 & 0 & E2, E3 & & \\
\hline \multirow[t]{2}{*}{ Rhynchocyclidae } & Tolmomyias sulphurescens (2) & 1 & 50 & 1 & E1, E3 & & $1 \mathrm{~A}$. longirostre \\
\hline & Leptopogon amaurocephalus (1) & 0 & 0 & 0 & E1 & & \\
\hline \multirow[t]{2}{*}{ Tyrannidae } & Platyrinchus mystaceus (10) & 3 & 30 & 0.6 & $\mathrm{E} 1, \mathrm{E} 2, \mathrm{E} 3$ & 2 Amblyomma sp. & \\
\hline & Lathrotriccus euleri ( $($ ) & 4 & 66.6 & 1.75 & $\mathrm{E} 1, \mathrm{E} 3, \mathrm{E} 4$ & 4 Amblyomma sp. & $\begin{array}{l}2 \text { A. longirostre; } \\
1 \text { A. calcaratum }\end{array}$ \\
\hline \multirow[t]{2}{*}{ Pipridae } & Manacus manacus ( 1 ) & 0 & 0 & 0 & E3 & & \\
\hline & Antilophia galeata (2) & 1 & 50 & 5 & E2 & 5 Amblyomma sp. & \\
\hline Tityridae & Pachyramphus polychopterus (1) & 0 & 0 & 0 & E1 & & \\
\hline Vireonidae & Cyclarhis gujanensis (6) & 0 & 0 & 0 & $\mathrm{E} 1, \mathrm{E} 2, \mathrm{E} 3$ & & \\
\hline Troglodytidae & Troglodytes musculus (1) & 0 & 0 & 0 & E2 & & \\
\hline \multirow[t]{3}{*}{ Turdidae } & Turdus rufiventris (3) & 0 & 0 & 0 & E2 & & \\
\hline & Turdus leucomelas (9) & 5 & 55.5 & 1.8 & $\begin{array}{c}\text { E1, E2, E3, } \\
\text { E4 }\end{array}$ & 8 Amblyomma sp. & $1 \mathrm{~A}$. longirostre \\
\hline & Turdus subalaris (1) & 1 & 100 & 1 & E1 & 1 Amblyomma sp. & \\
\hline Coerebidae & Coereba flaveola (1) & 0 & 0 & 0 & $\mathrm{E} 1, \mathrm{E} 2, \mathrm{E} 3$ & & \\
\hline \multirow[t]{7}{*}{ Thraupidae } & Saltator similis (1) & 0 & 0 & 0 & E1 & & \\
\hline & Thlypopsis sordida (1) & 0 & 0 & 0 & E2 & & \\
\hline & Tachyphonus coronatus (8) & 4 & 50 & 2 & $\mathrm{E} 2, \mathrm{E} 3, \mathrm{E} 4$ & 7 Amblyomma sp. & 1 A. longirostre \\
\hline & Ramphocelus carbo (1) & 0 & 0 & 0 & E2 & & \\
\hline & Lanio penicillatus ( 1 ) & 0 & 0 & 0 & E1 & & \\
\hline & Lanio melanops (3) & 0 & 0 & 0 & E1 & & \\
\hline & Trichothraupis melanops (4) & 4 & 100 & 1.25 & E4 & 5 Amblyomma sp. & \\
\hline \multirow[t]{2}{*}{ Emberizidae } & Sporophila caerulescens (1) & 1 & 100 & 2 & E2 & 2 Amblyomma sp. & \\
\hline & Arremon flavirostris (3) & 0 & 0 & 0 & E2, E3 & & \\
\hline Cardinalidae & Habia rubica (2) & 0 & 0 & 0 & E3 & & \\
\hline \multirow[t]{2}{*}{ Parulidae } & Basileuterus hypoleucus (G) & 1 & 16.6 & 1 & $\mathrm{E} 1, \mathrm{E} 2, \mathrm{E} 3$ & & $1 \mathrm{~A}$. longirostre \\
\hline & Basileuterus flaveolus (9) & 0 & 0 & 0 & $\mathrm{E} 1, \mathrm{E} 2, \mathrm{E} 3$ & & \\
\hline
\end{tabular}


Bird species parasitized by $A$. longirostre were Lanio penicillatus, L. melanops, Taraba major, Sittasomus griseicapillus, Tolmomyias sulphurescens, L. euleri, T. leucomelas, Tachyphonus coronatus and Basileuterus hypoleucus. Labruna et al. (2007) and Tolesano-Pascoli et al. (2010) reported A. longirostre on these same bird species in the Brazilian Atlantic Forest and Cerrado.

The species $A$. longirostre is a Neotropical tick widely distributed throughout South and Central America (GUGLIELMONE et al., 2003). Adults of this tick species feed primarily on porcupines, while its larvae and nymphs are frequently found on passerine birds (ARAGÃO, 1936; VENZAL et al., 2005; OGRZEWALSKA et al., 2010; TOLESANO-PASCOLI et al., 2010). Labruna et al. (2007) proposed that this tick might have an arboreal life cycle, since most of the birds species found parasitized by immature stages of $A$. longirostre were arboreal, some of them with no ground visiting habits.

Ogrzewalska (2009) suggested that different species of ticks respond differently to fragmentation; moreover, the prevalence of each tick species might be related to the abundance of their adult stage hosts. In fact, the tick species distribution found in this study can be related to the different ways that fragmentation affects anteaters and porcupines. Porcupines seem able to occupy anthropogenic habitats, while anteaters are more sensitive to the impacts of fragmentation (FAHRIG, 2001; HENLE et al., 2004).

Birds of the genus Turdus were previously reported to be important for the life cycle of several tick species, once they live in low forest stratum and are commonly found on the ground (ROJAS et al., 1999; ARZUA et al., 2003; VENZAL et al., 2005). In this study, we observed this bird genus parasitized by Amblyomma larvae, and nymphs of $A$. calcaratum and $A$. longirostre, with high prevalence and mean intensity.

The bird species $H$. rubica, $P$. mystaceus and D. platyrostris were recaptured in different plots, and although under very low infestation, they can act scattering ticks to other environments.

In conclusion, birds seem to play a fundamental role in the life cycle of some tick species; furthermore, wild birds have been associated with the transportation of infected ticks through lands and abroad continents, acting as long-distance vectors for several pathogens of human and animal diseases (BJÖERSDORFF et al., 2001; GEORGOPOULOU; TSIOURIS, 2008).

\section{Acknowledgements}

The authors are grateful to the 'Centro Nacional de Pesquisa para Conservação de Aves Silvestres,' 'Instituto Chico Mendes de Conservação da Biodiversidade' (CEMAVE/ICMBIO), 'Fundação de Amparo à Pesquisa do Estado de São Paulo' (FAPESP), 'Conselho Nacional de Desenvolvimento Científico e Tecnológico' (CNPq) and 'Universidade Estadual Paulista Júlio de Mesquita Filho' (UNESP), Rio Claro, State of Sao Paulo, Brazil.

\section{References}

Aragão HB. Ixodidas brasileiros e de alguns paizes limitrophes. Mem Inst Oswaldo Cruz 1936; 31(4): 759-843. http://dx.doi.org/10.1590/ S0074-02761936000400004
Arzua M, Navarro da Silva MA, Famadas KM, Beati L, Barros-Battesti DM. Amblyomma aureolatum and Ixodes auritulus Neumann (Acari: Ixodidae) on birds in southern Brazil, with notes on their ecology. Exp Appl Acarol 2003; 31(3-4): 283-296. PMid:14974693. http://dx.doi. org/10.1023/B:APPA.0000010381.24903.1c

Bjöersdorff A, Bergström S, Massung RF, Haemig PD, Oslen B. Ehrlichiainfected ticks on migrating birds. Emerg Infect Dis 2001; 7(5): 877-879. PMid:11747702 PMCid:2631880.

Bush AO, Lafferty KD, Lotz JM, Shostak AW. Parasitology meets ecology on its own terms: Margolis et al. revisited. J Parasitol 1997; 83(4): 575-583. PMid:9267395. http://dx.doi.org/10.2307/3284227

Comitê Brasileiro de Registros Ornitológicos - CBRO. Lista das aves do Brasil. Epi Info [online]. 2011 [cited 2012 Jan 27]. Available from: http://cbro.org.br.

Elfving K, Oslen B, Bergström S, Waldenström J, Lundkvist A, Sjöstedt A, et al. Dissemination of Spotted Fever Rickettsia agents in Europe by migrating birds. PLoS One 2010; 5(1): e8572. PMid:20052286 PMCid:2797135. http://dx.doi.org/10.1371/journal.pone.0008572

Emmons L, Feer F. Neotropical rainforest mammals: a Field Guide. Chicago: University of Chicago Press; 1997.

Fahrig L. How much habit is enough? Biol Conserv 2001; 100(1): 65-74. http://dx.doi.org/10.1016/S0006-3207(00)00208-1

Georgopoulou I, Tsiouris V. The potential role of migratory birds in the transmission of zoonoses. Vet Ital 2008; 44(4): 671-677. PMid:20411494.

Guglielmone AA, Estrada-Peña A, Keirans JE, Robins RG. Ticks (Acari: Ixodidae) of the Neotropical Zoogeographic Region. Atlanta: International Consortium of Ticks and Tick-borne Diseases; 2003. PMCid:207124.

Henle K, Davies KF, Kleyer M, Margules C, Settele J. Predictors of Species Sensitivity to Fragmentation. Biodiversity Conserv 2004; 13(1): 207-251. http://dx.doi.org/10.1023/B:BIOC.0000004319.91643.9e

Hildebrandt A, Franke J, Meier F, Sachse F, Dorn W, Straube E. The potential role of migratory birds in transmission cycles of Babesia spp., Anaplasma phagocytophilum, and Rickettsia spp. Ticks Tick Borne Dis 2010; 1(2): 105-107. PMid:21771516. http://dx.doi.org/10.1016/j. ttbdis.2009.12.003

Jones EK, Clifford CM, Keirans JE, Kohls GM. The ticks of Venezuela (Acarina: Ixodoidea) with a key to the species of Amblyomma in the Western hemisphere. Brigham Young Univ Sci Bull Biol Ser 1972; 17(4): 1-40.

Jongejan F, Uilenberg G. The global importance of ticks. Parasitology 2004; 129: S3-S14. PMid:15938502. http://dx.doi. org/10.1017/S0031182004005967

Labruna MB, Sanfilippo LF, Demetrio C, Menezes AC, Pinter A, Guglielmone AA, et al. Ticks collected on birds in the state of São Paulo, Brazil. Exp Appl Acarol 2007; 43(2): 147-160. PMid:17882514. http:// dx.doi.org/10.1007/s10493-007-9106-x

Martins TF, Onofrio VC, Barros-Battesti DM, Labruna MB. Nymphs of the genus Amblyomma (Acari: Ixodidae) of Brazil: Descriptions, redescriptions, and identification key. Ticks Tick Borne Dis 2010; 1(2): 75-99. PMid:21771514. http://dx.doi.org/10.1016/j. ttbdis.2010.03.002

Ogrzewalska M, Pacheco RC, Uezu A, Ferreira A, Labruna MB. Ticks (Acari: Ixodidae) infesting wild birds in an Atlantic Forest area in the state of São Paulo, Brazil, with isolation of Rickettsia from the tick 
Amblyomma longirostre. J Med Entomol 2008; 45(4): 770-774. http:// dx.doi.org/10.1603/0022-2585(2008)45[770:TAIIWB]2.0.CO;2

Ogrzewalska M. Efeito da fragmentaçâo florestal na infestação por carrapatos (Acari: Ixodidae) em aves e infecção de carrapatos por Rickettsia spp. no Pontal do Paranapanema, SP [Tese]. São Paulo: Universidade de São Paulo; 2009.

Ogrzewalska M, Uezu A, Labruna MB. Ticks (Acari: Ixodidae) infesting wild birds in the eastern Amazon, northern Brazil, with notes on rickettsial infection in ticks. Parasitol Res 2010; 106(4): 809-816. PMid:20140452. http://dx.doi.org/10.1007/s00436-010-1733-1

Ogrzewalska M, Uezu A, Labruna MB. Ticks (Acari: Ixodidae) infesting wild birds in the Atlantic forest in northeastern Brazil, with notes on rickettsial infection in ticks. Parasitol Res 2011; 108(3): 665-670. PMid:20953629. http://dx.doi.org/10.1007/s00436-010-2111-8

Onofrio VC, Venzal JM, Pinter A, Szabó MPJ. Família Ixodidae: características gerais, comentários e chaves para gêneros. In: BarrosBattesti DM, Arzua M, Bechara GH. Carrapatos de importância medicoveterinária da região neotropical: um guia ilustrado para identificação de espécies. São Paulo: Vox/ICTTD-3, Butantan; 2006. p. 29-39.

Rojas R, Marini MÂ, Zanatta Coutinho AT. Wild birds as hosts of Amblyomma cajennense (Fabricius, 1787) (Acari: Ixodidae). Mem Inst
Oswaldo Cruz 1999; 94(3): 315-322. PMid:10419381. http://dx.doi. org/10.1590/S0074-02761999000300007

Santos-Silva MM, Sousa R, Santos AS, Melo P, Encarnação V, Bacellar F. Ticks parasitizing wild birds in Portugal: Detection of Rickettsia aeschlimannii, R. helvetica and R. massiliae. Exp Appl Acarol 2006; 39(3-4): 331-338. PMid:16897568. http://dx.doi. org/10.1007/s10493-006-9008-3

Sick H. Ornitologia brasileira. Rio de Janeiro: Nova Fronteira; 1997.

Sigrist T. Aves do Brasil Oriental. São Paulo: Avis Basilis; 2009.

Souza D. All the birds of Brazil: an identification guide. Dall, Subbuteobooks; 2002.

Tolesano-Pascoli GV, Torga K, Franchin AG, Ogrzewalska M, Gerardi M, Olegário MM, et al. Ticks on birds in a Forest fragment of Brazilian cerrado (savanna) in the municipality of Uberlândia, State of Minas Gerais, Brazil. Rev Bras Parasitol Vet 2010; 19(4): 244-248. PMid:21184702. http://dx.doi.org/10.1590/S1984-29612010000400010

Venzal JM, Félix ML, Olmos A, Mangold AJ, Guglielmone AA. A collection of ticks (Ixodidae) from wild birds in Uruguay. Exp Appl Acarol 2005; 36(4): 325-331. PMid:16132744. http://dx.doi. org/10.1007/s10493-005-8433-z 